\title{
K POSTAVENÍ OPOZIČNÍHO POSLANCE V LEGISLATIVNÍM PROCESU ZA PRVNÍ REPUBLIKY*
}

\author{
JINDŘIŠKA SYLLOVÁ
}

\begin{abstract}
On the status of opposition deputies in the legislative procedure in the First Czechoslovak Republic

If we compare the current tendencies to restrict the rights of individual MPs to submit bills and amendments, to limit the right of speech, with the First Republic, the current efforts get closer to the First-Republic practice. The paper is describing legal provisions dealing with the individual MPs' rights of the First-Republic rules of procedure.

Contemporary tendencies agree with the departure from strong MPs' individualism, which emerged as a negation of socialist voting unanimity. We may also observe the shift towards higher parliamentary party discipline, which corresponds to the characteristics of the Parliament of the First Republic.
\end{abstract}

Keywords: bills; private bills; amendments; speech limitation; First Czechoslovak Republic

Klíčová slova: návrh zákona; poslanec; pozměňovací návrh; omezení řečnické doby; první republika

DOI: $10.14712 / 23366478.2018 .20$

\section{ÚVOD}

Poslední volební období Poslanecké sněmovny (sedmé volební období, léta 2013-2017) se vyznačovalo pokusy některých sněmovních stran o zkrácení určitých práv opozice při legislativní práci. Tyto snahy nezůstaly jen ve slovních projevech, jednalo se o reálné pokusy vtělené do návrhů na novelizaci jednacího řádu Poslanecké sněmovny. Další návrhy v tomto směru se objevily u kulatého stolu pro revizi Ústavy, který byl veden ministrem pro legislativu v r. 2017.

Zkrácení řečnické doby poslance $\mathrm{v}$ rozpravě bylo obsaženo už na počátku 7 . volebního období Poslanecké sněmovny v tisku č. 26 (7. volební období, dále jen VO, r. 2013). V ustanovení $§ 53$ jednacího řádu Poslanecké sněmovny v pasáži upravující projevy při schvalování pořadu schůze ${ }^{1}$ bylo navrhováno, aby bylo stanoveno: ,... Při

* Tento článek byl vypracován v rámci programu PROGRES Q04. Autorka je externí spolupracovnicí katedry ústavního práva PF UK. Je odborným konzultantem Parlamentního institutu Poslanecké sněmovny.

1 Nejedná se o rozpravu, která se při této př́ležitosti nekoná. S projevem však mohou vystoupit řečníci s přednostním právem, což přípravu programu neúnosně protahuje. 
projednávání pořadu schůze a při projednávání návrhů na jeho změnu nebo doplnění se délka př́spěvku jednotlivého poslance omezuje na maximálně dva př́spěvky, každý v maximální délce 10 minut.“ Návrh nebyl schválen.

Dále se objevila snaha o omezení poslaneckých pozměňovacích návrhů, a to v tom směru, aby měly pozměňovací návrhy důvodovou zprávu, tedy aby se podávaly písemně. Opět v tisku č. $26(7 \text {. VO, 2013) })^{2}$ bylo do $\S 63$ odst. 1 bod 5 jednacího řádu Poslanecké sněmovny navrhováno: „d) pozměňovací návrh musí obsahovat př́lohu s vyznačením změn a odůvodnění, které vysvětlí jeho nezbytnost, vztah k návrhu zákona jako celku a k jeho jednotlivým ustanovením, slučitelnost s mezinárodními smlouvami podle čl. 10 Ústavy a s ústavním pořádkem České republiky, předpokládaný hospodářský a finanční dosah přijetí pozměňovacího návrhu a zhodnocení korupčních rizik. Předpokládá-li pozměňovací návrh vydání prováděcího předpisu, musí odůvodnění pozměňovacího návrhu obsahovat i podrobný popis úpravy prováděcího předpisu, jinak je nepř́pustný. “3 Tato část návrhu nebyla do novely jednacího rádu zapracována. Určitá omezení pozměňovacích návrhů obsahovaly i dř́vější návrhy novel jednacího řádu Poslanecké sněmovny, napřs. tisk 577 z 6 . VO měl zakázat komplexní pozměňovací návrhy. Rovněž nebyl přijat.

Vládní iniciativa z r. 2017 nazvaná Kulatý stůl o možných změnách Ústavy navrhla, že žádoucí změna ústavy by měla spočívat $v$ tom, že ,zákonodárnou iniciativu by neměl mít jednotlivý poslanec, ale skupina poslanců (nejméně 5 , alt. nejméně 10 poslanců)““. 4

Pro zde předkládaný historicky zaměřený text jsem konfrontovala tyto pokusy s prvorepublikovou praxí. Text má odpovědět na otázku, jak byly legislativní činnosti opozice upraveny a uskutečňovány v předobrazu dnešního parlamentu, tedy ve sněmovnách Národního shromáždění v období první republiky. Aby nebyl text přetížen, soustředila jsem se pouze na tři instituty - právo jednotlivého poslance navrhnout návrh zákona, právo jednotlivého poslance navrhnout pozměňovací návrh $\mathrm{k}$ návrhu zákona a právo poslance vystoupit $\mathrm{v}$ rozpravě.

Pokud vycházíme z obecného povědomí o jednání prvorepublikové poslanecké sněmovny, mohli bychom se domnívat, že standardy demokratického parlamentu na počátku 20. století byly sice odlišné od současného stavu, nicméně že základy nezbytné pro demokratické postavení opozice $\mathrm{v}$ zákonodárství byly už tehdy shodné jako v současnosti. Ačkoliv byly demokratické instituty týkající se práv poslanců při legislativním procesu upraveny a zásadně garantovány $\mathrm{v}$ jednacích řádech parlamentních sborů Rakousko-Uherského soustátí druhé poloviny 19. století, ${ }^{5}$ základní demokratická práva opozice $\mathrm{v}$ legislativním procesu byla plně založena $\mathrm{v}$ parlamentu první republiky a tato práva jsou srovnatelná se současným standardem. ${ }^{6}$

Jednací pravidla prvorepublikového parlamentu byla přijata podobně jako pravidla současná ve formě zákona, i když byla později Ústavní listinou umožněna autonomní mimozákonná forma. Odborná literatura se vyjadřuje k prvnímu znění jednacího řádu

\footnotetext{
Podobný návrh byl i v návrhu novely jednacího řádu PS č. 1029 z r. 2013 (6. VO). Návrh nebyl přijat. Důvodovou zprávu měla mít i usnesení výboru, která poslanecký pozměňovací návrh doporučila plénu. Výsledky jednání kulatých stolů o možných změnách Ústavy ČR. Praha: Úřad vlády ČR, 2017.

Zejména v jednacím řádu poslanecké sněmovny říšské rady z r. 1861.

6 BAXA, B. Parlament a parlamentarism: Parlament, jeho vývoj, složení a funkce. Praha, Jan Košatka. 1924.
} 
(jednokomorového) Národního shromáždění - zákona č. 36/1918 Sb. z. a n. poněkud kriticky v tom smyslu, že jednací rád ,byl zpracován narychlo hlavně na podkladě jednacího řádu sněmu království českého a poslanecké sněmovny rady říšské ve Vídni."7 Obsah prvního jednacího řádu Národního shromáždění byl poté do velké míry převzat do oddělených zákonů - jednacích řádů obou sněmoven, které byly schváleny v r. 1920 pod čísly 325/1920 Sb. z. a n. a 326/1920 Sb. z. a n. a které zůstaly v platnosti ve formě zákona až konce první republiky, resp. ještě déle. ${ }^{8}$

\section{ZÁKONODÁRNÁ INICIATIVA POSLANCŮ}

Zákonodárná iniciativa byla upravena v prvním jednacím řádu Národního shromáždění č. 36/1918 Sb. z. a n. takto: „, 14 Národní shromáždění jedná o návrzích vládnich, o návrzich jednotlivých poslanců a o peticich a interpelacich. § 15 Aby Národni shromáždéní jednalo o návrhu jednotlivého poslance, musí návrh býti podepsán nebo podporován aspoň dvaceti jinými poslanci. "

Poněkud odlišnou formulaci stanoví o dva roky později Ústavní listina: ,, \$ 41 (1) Návrhy zákonů mohou vycházeti bud' od vlád nebo od jakékoli sněmovny. (2) Ke každému návrhu zákona, podanému členy některé sněmovny, budiž přiložen rozpočet o finančním dosahu osnovy a návrh na úhradu potřebného nákladu. "

Ústavní ustanovení tím, že stanovilo sousloví „podanému členy některé sněmovny,“ mohlo být zamýšleno i tak, že zákonodárnou iniciativu má mít každý člen Národního shromáždění. Př̀i tvorbě jednacích řádů komor v r. 1920 ale byla přijata úprava kontinuitní $\mathrm{k}$ dosavadnímu jednacímu řádu, ${ }^{9}$ počítající s povinnou podporou návrhu zákona určitým počtem členů př́slušné komory. Ústavní formulace tento výklad umožňovala. Ustanovení § 19 odst. 1 jednacího řádu poslanecké sněmovny č. 325/1920 Sb. z. a n. stanovilo, že „návrhy vládní, pak samostatné (iniciativní) návrhy poslanců, podané písemně ve sněmovní kanceláři a podepsané aspoň 20 jinými poslanci, se vytisknou...". Podobně jednací řád senátu ${ }^{10}$ vyžadoval pro návrhy samostatné podporu doloženou podpisy 10 jiných senátorů. Návrhy zákonů se přitom považovaly za návrhy těch poslanců či senátorů, kteří pod nimi byli podepsáni, prvotní navrhovatel i ostatní podepsaní podporovatelé měli při dispozici s návrhem shodné procesní postavení.

Pravidla stanovená jednacím rádem pro nezávislé návrhy (které se nazývaly iniciativní návrhy) byla př́isnější než pro vládní návrhy zákonů. Zejména podmínka uvedení

7 ŘíHA, J. Jednací řády parlamentní. In: HÁCHA, E. a další, Slovník veřejného práva československého. Svazek II. Brno: Polygrafia, 1932, str. 79.

8 Kromě zákonného textu se za součást jednacího řádu každé sněmovny považovala zvláštní usnesení, která jej prováděla. Tato usnesení však byla využívána jen minimálně.

9 Zdrojem ustanovení byl jednací rád českého zemského sněmu, ve kterém už v r. 1863 (až do konce jeho fungování) byla v $\$ 37$ pro poslanecké návrhy vyžadována podpora 20 jiných poslanců. In: Jednací rád pro český sněm zemský (1867) Praha: tiskem Hynka Fukse, str. 13. Kromě samostatných návrhů umožňoval zákonodárnou iniciativu i výboru zemskému, zvláštním výborům a nejvyššímu maršálkovi zemskému. Stejné pravidlo o 20 poslancích obsahoval i jednací rád poslanecké sněmovny říšské rady z r. 1867, a to $\mathrm{v} \S 18$, kde bylo umožněno podporu poslanců doplnit ústně, pokud pod návrhem bylo méně než 20 podpisù. $\mathrm{V}$ tomto jednacím řádu byla rovněž umožněna zákonodárná iniciativa některých orgánům sněmovny.

10 Zákon č. 326/1920 Sb. z. a n. 
finančního dosahu a výdajů v př́padě schválení osnovy zákona byla stanovena jen pro poslanecké (a jednacím rádem senátu pro senátorské) návrhy zákonů. Slovník veřejného práva k tomu konstatuje, že toto znevýhodnění bylo nepodstatné. Jednak finanční dosah obsahovaly v odůvodnění osnovy i vládní návrhy zákonů, jednak iniciativní výbor aplikoval toto ustanovení benevolentně. ${ }^{11}$

Pro legislativní návrhy poslanců poslanecké sněmovny dále platilo, že je předběžně projednával výbor iniciativní. ${ }^{12}$ Vládní návrhy zákonů iniciativní výbor neprojednával. Podle $\S 19$ jednacího řádu poslanecké sněmovny byl předseda sněmovny povinen vládní návrhy po rozeslání členům sněmovny přikázat „,V příští schůzi“ př́mo odbornému výboru. ${ }^{13}$ Iniciativní výbor rozhodoval o tom, zda bude o nevládním návrhu sněmovna vůbec jednat, sám iniciativní výbor mohl poslanecký návrh zákona zamítnout, a to bez uvedení důvodu, musel ale dodržet lhůtu 30 dnů. Pokud tak neučinil včas, měl předseda sněmovny povinnost přikázat iniciativní návrh věcnému výboru. Pokud iniciativní výbor návrh zamítl, mohl kterýkoli z navrhovatelů nevládního návrhu zákona navrhnout, aby sněmovna odmítavé usnesení iniciativního výboru změnila. Předseda iniciativního výboru pak měl povinnost tento návrh plénu předložit ,v jedné z nejbližších schůzi““. Poslanecká sněmovna hlasovala o změně zamítavého rozhodnutí iniciativního výboru. Dokonce bylo stanoveno, že o osudu iniciativních návrhů v této fázi mohlo plénum hlasovat podle $\S 23$ odst. 5 tak, že mohlo hlasovat najednou o více různých návrzích, tedy tzv. hromadným hlasováním.

Nevládní návrhy měly i další procesní nevýhody. Iniciátoři je nesměli podle jednacího rrádu vůbec sami vzít zpět. Rovněž je nesměli podat znovu po dobu 6 měsíců od jejich zamítnutí at' už iniciativním výborem, nebo plénem. ${ }^{14}$

Profesor Zdeněk Peška v komentári cituje důvodovou zprávu, která ukazuje, jakým způsobem o nevládních návrzích uvažoval výbor pro jednací rád, který se v r. 1920 tvorbě jednacího rrádu a posléze jeho navrhovaným změnám věnoval. Výbor se obával velkého zatížení předsedy sněmovny, pokud by měl sám rozhodovat o všech návrzích. Úkolem iniciativního výboru bylo ulehčit jeho práci, ,jakož i zameziti, aby samostatné návrhy, jež nebyly podány v zájmu věci, nebo se jinak k projednání nehodí, zatěžovaly jiné výbory sněmovní. Tato instituce je převzata z parlamentárního práva francouzského, kde se znamenitě osvědčila... Iniciativní výbor vhodně nahradí starý způsob předběžného projednávání hlavních zásad návrhu v plenu sněmovny ve formě dřívějšího prvního čtení... Poslancům i plenu sněmovny poskytuje možnost kontroly výboru iniciativního jednak tisk samostatných návrhů, jednak oprávnění dovolati se konečného rozhodnutí plné sněmovny." ${ }^{15}$ Podle důvodové zprávy k jednacímu řádu poslanecké

11 ŘíHA, J. Jednací řády parlamentní. In: HÁCHA, E. a další, Slovnik veřejného práva československého, Svazek II. Brno: Polygrafia, 1932, str. 90.

12 „Pojmenování toho výboru jako „iniciativního“ nezdá se arcit’ býti vhodným. Jedná sice o iniciativních návrzích, ale nijak není povolán $\mathrm{k}$ tomu, aby snad povšechně povzbuzoval členy sněmovny iniciativnímu podávání návrhů nebo snad sám tuto iniciativu vykonával, nýbrž má naopak tuto iniciativní činnost brzditi.“WEYR, F. Soustava československého práva státního. Brno: Barvič a Novotný, 1921, str. 141.

13 Srov. WEYR, F. Soustava československého práva státního. Brno: Barvič a Novotný, 1921, str. 137.

14 Pokud byl nevládní návrh schválen jednou ze sněmoven, další postup ve druhé sněmovně př́ípadně návrat do sněmovny původní neobsahoval žádné rozdíly ve srovnání s návrhem vládním.

15 PEŠKA, Z. Československá ústava a zákony s ní souvislé. Praha: Československý Kompas, 1935, str. 1214. Zpráva výboru pro jednací řád Národního shromáždění, č. 2750/1920. 
sněmovny byl iniciativní výbor založen ,po vzoru francouzském“. Důvodová zpráva dále uváděla, že „lze očekávati, že kluby vyšlou zejména do tohoto výboru vynikající členy, takže takto složený výbor posoudí, zda návrh po stránce formální i věcné jest způsobilý vůbec nebo dočasně k řádnému projednání výborem i sněmovnou." ${ }^{16}$

„Výbor uvažoval i o tom, že zda by se nedoporučovalo, aby vládním návrhům dána byla přednost před návrhy iniciativními, ${ }^{17}$ nebo zda po vzoru jiných sněmoven (Order days $\mathrm{v}$ anglické sněmovně) nemají se vyhraditi pro projednání vládních návrhů zvláštní schůze v určité, předem stanovené dny v týdnu. Pro naprostou přednost vládních návrhů před návrhy iniciativními nemohl se výbor rozhodnouti, poněvadž konečné rozhodování mezi konkurujícími zájmy vlády, politických stran a jednotlivých poslanců musil vyhraditi sněmovně, jejíž většina ustanovuje s konečnou platností pořad jednání. Aby vyhrazeny byly vládním návrhů zvláštní dny v týdnu, to výbor nepovažuje za vhodné a chce ponechati sněmovně svobodu při stanovení pracovního programu." 18

Prvorepubliková odborná literatura otázku nevládních zákonodárných iniciativ komentovala souhrnně z hlediska praxe jen tak, že výbor iniciativní byl vǔči poslaneckým návrhům mírný a dovolil postup těchto návrhů k odborným výborům. Pokud nahlédneme do databáze parlamentních tisků Národního shromáždění první republiky, je zřejmé, že podávání poslaneckých - tzv. iniciativních - návrhů bylo jak v Revolučním národním shromáždění, tak v poslanecké sněmovně i senátu Národního shromáždění (1920-1938) obvyklou a oblíbenou praxí. Došlé poslanecké návrhy, které předsedající oznamoval vždy na začátku schůze, převažovaly vždy svým počtem nad návrhy vládními. Z komentáři̊ parlamentní činnosti vyplývá, že po skončení prvního volebním období Národního shromáždění (1925), kdy se částečně upevnila pozice vlády vi̊či poslanecké sněmovně, což se stalo zejména vlivem pevnějšího politického rrízení vlády, ${ }^{19}$ úspěšnost poslaneckých a senátorských návrhů zákonů klesala, a s následně (nevýznamně) poklesla i intenzita jejich podávání.

Zde uvádíme základní statistiku prvorepublikového zákonodárství od r. 1918 (tedy včetně Revolučního Národního shromáždění) až do r. 1938.

\begin{tabular}{|c|c|c|c|c|}
\hline $\begin{array}{l}\text { Počet vládních návrhů } \\
\text { zákonů do obou } \\
\text { komor1918-1928 }\end{array}$ & $\begin{array}{l}\text { Počet iniciativních návrhů } \\
\text { ve sněmovně (do r. } 1920 \text { do } \\
\text { Národního shromáždění) }\end{array}$ & $\begin{array}{l}\text { Počet iniciativních } \\
\text { návrhů v Senátu } \\
\text { (od r. 1920) }\end{array}$ & $\begin{array}{l}\text { Počet } \\
\text { schválených } \\
\text { zákonů }\end{array}$ & $\begin{array}{c}\% \\
\text { schválení }\end{array}$ \\
\hline $928+211$ tj. 1139 & 2356 & 451 & 1007 & $26 \%$ \\
\hline $\begin{array}{l}\text { Počet vládních návrhů } \\
\text { zákonů do obou } \\
\text { komor1928-1938 }\end{array}$ & $\begin{array}{l}\text { Počet iniciativních návrhů } \\
\text { ve sněmovně }\end{array}$ & $\begin{array}{l}\text { Počet iniciativních } \\
\text { návrhů v Senátu }\end{array}$ & $\begin{array}{l}\text { Počet } \\
\text { schválených } \\
\text { zákonů }\end{array}$ & $\begin{array}{c}\% \\
\text { schválení }\end{array}$ \\
\hline $436+313$ tj. 749 & 1684 & 577 & 417 & $17 \%$ \\
\hline
\end{tabular}

16 Tisk č. 2750/1920, citováno podle WEYR, F. Soustava československého práva státního. Brno: Barvič a Novotný, 1931, str. 141.

17 Což bylo stanoveno výslovně v jednacích řádech poslanecké sněmovny říšské rady v Rakousku-Uhersku.

18 PEŠKA, Z. Československá ústava a zákony s ní souvislé. Praha: Československý Kompas, 1935, str. 1209.

19 BAXA, B. Parlament a parlamentarismus. In: HÁCHA, E. a další, Slovník verejného práva československého. Svazek III. Brno: Polygrafia, 1934, str. 19. 
Z tabulky vyplývá, že počet iniciativních návrhů po celé prvorepublikové období skutečně výrazně převyšoval počet návrhủ vládních. Tento závěr poněkud devalvuje skutečnost, že mezi iniciativní návrhy byly zařazovány i tzv. rezoluční návrhy, které iniciovaly rezoluce (usnesení), nemuselo tedy jít o návrh zákona. Jejich podíl vzhledem k návrhům zákonů není statisticky podchycen. Přesto je zrejmé, že počet poslaneckých návrhů byl vysoký. Statistika poměru mezi vládními a iniciativními návrhy ohledně toho, kolik z nich bylo schváleno, není v souhrnu za celé zkoumané období k dispozici.

$\mathrm{Z}$ údajů z jednotlivých vládních a volebních období ${ }^{20}$ (které jsou $\mathrm{k}$ dispozici jen roztř̌́šsěně) vyplývá, že většina schválených návrhů zákonů byly zákony vládní. Např́iklad za úřednické Černého vlády v letech 1920-1921 bylo podáno přes 500 iniciativních návrhů, z nich bylo přijato jen 22. Z vládních návrhů, kterých bylo v témže období 197, bylo přitom schváleno $68 . .^{21}$

Mimo předmět tohoto článku je možno poukázat na zajímavou shodu v počtu schvalovaných návrhů zákonů. V prvních 10 letech první republiky se pohyboval roční průměr schválených zákonů okolo čísla 100 , což je podobné jako v současnosti. ${ }^{22} \mathrm{Ve}$ druhém desetiletí první republiky byl počet přijatých zákonů za rok podstatně nižší a pohyboval se okolo čísla 50 .

Je zřejmé, že procento vládních návrhů, které byly schváleny Národním shromážděním za první republiky, vůči podaným vládním návrhům, nebylo např. ve srovnání $\mathrm{s}$ dnešní praxí23 vysoké. Svou roli v malé legislativní úspěšnosti vládních návrhů hrála skutečnost, že se vlády po celé meziválečné období rychle stř́ídaly a málokterá přesáhla významně jeden rok trvání. Procento schválení vládních návrhů se významně zvýšilo po r. 1925.

Závěrem k této pasáži je možno konstatovat, že zákonodárná iniciativa poslanců byla za první republiky zdrojem prodlužování plenárních jednání, a to přesto, že některé poslanecké návrhy nebyly v plénu vůbec projednány, a to bud' kvưli jejich zamítnutí v iniciativním výboru, nebo kvưli zamítnutí odvolání navrhovatele plénem, nebo kvůli zdržovací taktice ve výborech. Celkově je možno uzavřít, že ani existence a činnost iniciativního výboru nezabránila účinným způsobem nadměrné zákonodárné iniciativě poslanců, která musela být omezována s použitím jiných institutů jednacího rádu.

Tabulka níže ukazuje počet jednacích dnů v poslanecké sněmovně první republiky ve dvacátých letech, vynechány jsou volební roky. V levých sloupcích je provedeno namátkové srovnání s 3. a 6. volebním obdobím současné Poslanecké sněmovny, vynechány jsou opět volební roky. Je třeba mít na mysli, že poslanecká sněmovna měla za první republiky 300 poslanců. Zajímavé je, že za první republiky se počet jednacích dnů postupně spíše snižoval, v současnosti ve srovnání s obdobím před 15 lety spíše stoupá.

20 Údaje jsou vybrány z publikací: Národni shromážděni Republiky Československé v prvém desetiletí. Praha: Předsednictvo senátu a Předsednictvo poslanecké sněmovny, 1928; stejná publikace pro druhé desetiletí, vydána 1938.

21 Viz předchozí poznámka.

22 V sedmém volebním období Poslanecké sněmovny (2013-2017) bylo schváleno za 4 roky 357 zákonů.

23 7. volební období PS v letech 2013-17, 376 vládních návrhů podaných, 302 schválených. 


\begin{tabular}{|c|c|c|c|}
\hline Posl. sněmovna Rok & Počet jednacích dnů & \\
\hline 1921 & 73 & Posl. sněmovna Rok & Počet jednacích dnů $^{25}$ \\
\hline 1922 & 61 & 1999 & 69 \\
\hline 1923 & 51 & 2000 & 71 \\
\hline 1924 & 64 & 2001 & 73 \\
\hline & & & \\
\hline 1926 & 49 & & 73 \\
\hline 1927 & 52 & 2014 & 75 \\
\hline 1928 & 54 & 2015 & 77 \\
\hline
\end{tabular}

Nadměrná zákonodárná iniciativa poslanců je rys podobný současnému zákonodárnému aktivismu poslanců. ${ }^{26}$ Tento rys neoslabil za první republiky ani tím, že byla zákonodárná iniciativa umožněna jen skupinám alespoň 21 poslanců nebo 11 senátorů. Naopak, pokud si prohlédneme souhrnné zprávy o činnosti Národního shromáždění, ${ }^{27}$ je z nich možno vyčíst, že toto omezení individuálních návrhů vedlo k tomu, že iniciativní návrhy zákonů byly ve své většině podávány za politické kluby, a to jak kluby vládní, tak kluby opozičních politických stran. Stejné rysy se projevovaly v senátu. Tímto způsobem se iniciativa poslanců spíše posilovala, než oslabovala, protože kluby poskytovaly určité technické a odborné zázemí pro vytváření návrhů zákonů.

\section{PODÁVÁNÍ POZMĚŇOVACÍCH NÁVRHŮ POSLANCI}

V plénu poslanecké sněmovny platilo významné omezení podávání pozměňovacích návrhů poslance. Toto omezení platilo už od prvního jednacího řádu z r. $1918,{ }^{28}$ a přeneslo se do jednacího řádu z r. 1920. Věcné pozměňovací návrhy mohl podle $\S 48$ odst. 1 jednacího řádu poslanec podat jen tehdy, pokud bylo písemné znění návrhu podepsáno kromě navrhovatele ještě 20 jinými poslanci. ${ }^{29}$ Pro senát platilo, že návrhy musí být podepsány navrhovatelem a ještě alespoň 10 senátory. Toto drakonické omezení se vztahovalo na rozpravy o návrzích zákonů i na jiné rozpravy. Jednací řád pro plénum zároveň stanovoval obligatorní písemné podávání pozměňovacích návrhů, tedy předání písemného návrhu kanceláři s tím, že návrhy byly vytištěny spolu se zprávou výborovou jako písemný podklad pro prvé čtení. ${ }^{30}$

24 Pokud byly dvě schůze v jeden den, je počítán jeden jednací den, pokud byla jedna schůze 2 dny, jsou počítány dva jednací dny. Obvykle se jedna plenární schůze konala v jeden den.

25 Pokud se konalo v jednom dnu více schůzí, je započítán vždy jen jeden jednací den.

26 Srov. KOLÁŘ, P. - KYSELA, J. - SYLLOVÁ, J. a další. Parlament České republiky. Praha: Leges 2013.

27 Tamtéž.

28 § 52 Dokud debata není ukončena, může každý poslanec navrhovati změny projednávaného návrhu a doplňky k němu. I takový návrh musí býti podporován 20 jinými poslanci.

29 Návrh se nazýval jako návrh poslance XY a ,soudr.“.

30 ŘíHA, J. Jednací řády parlamentní. In: HÁCHA, E. a další, Slovník veřejného práva československého. Svazek II. Brno: Polygrafia, 1932, str. 93. 
Omezení podávání pozměňovacích návrhů logicky navazovalo na shodné omezení u podávání iniciativních návrhů zákonů. Tato regulace byla mimo jiné inspirována jednacím řádem Českého sněmu. ${ }^{31}$

Ve srovnání se současným stavem je zřejmé, že systém jednání poslanecké sněmovny byl extrémně silně navázán na politické kluby, individualismus poslanců byl tímto ustanovením silně potlačován. Tomu odpovídal i styl rozpravy a projevů. Při čtení stenografických záznamů pléna je možno dojít k závěru, že pozměňovací návrhy byly povětšině stranicky podpořené. Ustanovení o podpisech $\mathrm{k}$ podpoře pozměňovacího návrhu se nevykládalo př́liš striktně, pokud nějaký podpis u pozměňovacího návrhu chyběl do předepsaného počtu, vyzval předsedající navrhovatele, aby zařídil následné doplnění podpisů.

Aby nedocházelo $\mathrm{k}$ tomu, že se na projev poslance podávajícího pozměňovací návrh $\mathrm{v}$ rozpravě nedostane, protože bude předčasně ukončena, bylo třeba všechny pozměňovací návrhy podat písemně v kanceláři. To umožnilo připravit pro poslance písemný podklad k bodu jednání, kde byly podávané pozměňovací návrhy vytištěny.

Pokud byly podány pozměňovací návrhy, byl systém hlasování po prvním čtení odlišný od dnešního. Hlasovalo se po částech návrhu zákona, u částí, kde byly podány pozměňovací návrhy, se hlasovalo obvykle nejprve o pozměňovacím návrhu k příslušné části, když nebyl přijat, tak se schvalovala stejná část ve znění „,výborové zprávy“. Při hlasování v prvním čtení se takto pokračovalo až do konce návrhu zákona. ${ }^{32}$

Jednací řád poslanecké sněmovny neupravoval zásady podávání pozměňovacích návrhů ve výborech, pritom platilo, že výborové jednání se ř́dí normami pro plenární jednání, pokud není stanoveno něco jiného ( $\$ 25$ odst. 3 jednacího řádu poslanecké sněmovny). Výjimkou bylo to, že pozměňovací návrhy ve výborech mohli podávat jednotliví poslanci, pokud šlo o krátké a jednoduché návrhy, mohli je podávat ústně, pokud nepodala většina př́tomných proti této praxi povolené předsedou výboru písemně námitky ( $\$ 25$ odst. 4 jednacího řádu poslanecké sněmovny).

31 Jednací řád Českého zemského sněmu č. 56/1863 z. z., ve znění z r. 1867 to bylo upraveno v § 37, ve znění z r. 1889 a $1901 \mathrm{v} \S 39$.

32 Projednávání návrhu zákona tisk 1528 dne 14. 7. 1928: Předseda (zvoní): Přistoupíme ke hlasování. Osnova zákona má 26 paragrafů, nadpis a úvodní formuli. Poněvadž byly podány pozměňovací návrhy, míním dáti hlasovati takto: $\mathrm{O} \S \S 1$ až 7 budeme hlasovati podle zprávy výborové. $\mathrm{O}$ §u 8 dám hlasovati nejprve v úpravě návrhu posl. Bradáče, dr Dolanského, Windirsche, dr Kramáře, Mlčocha, dr Luschky, Stenzla a druhů; nebude-li přijata, hlasovali bychom podle zprávy výborové. O §u 9 budeme hlasovati podle zprávy výborové. O §u 10 budeme hlasovati nejprve v úpravě návrhů posl. Bradáče, dr Dolanského, Windirsche, dr Kramáŕe, Mlčocha, dr Luschky, Stenzla a druhů; nebude-li přijata, budeme hlasovati podle zprávy výborové. O $\S \S 11$ až 26 , nadpisu a úvodní formuli zákona dám hlasovati podle zprávy výborové. Jsou nějaké námitky proti přednesenému způsobu hlasování? (Nebyly.) Kdo souhlasí s $\S \S 1$ až 7 podle zprávy výborové, necht' zvedne ruku. (Děje se.) To je většina. $\S \S 1$ až 7 jsou přijaty podle zprávy výborové. Kdo souhlasí s §em 8 v úpravě návrhu posl. Bradáče, dr Dolanského, Windirsche, dr Kramáře, Mlčocha, dr Luschky, Stenzla a druhů, necht’ pozvedne ruku. (Děje se.) To je většina. Tím je přijat $\S 8 \mathrm{v}$ úpravě návrhu posl. Bradáče a druhů a odpadá hlasování podle zprávy výborové. Kdo souhlasí s §em 9 podle zprávy výborové, necht' pozvedne ruku. (Děje se.) To je většina. § 9 jest prijjat podle zprávy výborové. Kdo souhlasí s §em 10 v úpravě návrhu posl. Bradáče, dr Dolanského, Windirsche, dr Kramáře, Mlčocha, dr Luschky, Stenzla a druhů, nech pozvedne ruku. (Děje se.) 


\section{ÚPRAVA PROJEVU゚ POSLANCŮ}

Projevy poslanců byly podle prvorepublikového jednacího řádu omezeny jak v délce, tak v četnosti. Jednací rád pro rozpravu závazně stanovil, že žádný poslanec nesmí mluviti $k$ témuž předmětu jednání více než dvakráte ( $\$ 45$ odst. 5), to však neplatilo na členy vlády, kteří směli vystoupit kdykoliv a co do počtu vystoupení neomezeně (§ 46 jednacího rádu poslanecké sněmovny, stejně v senátu). Sněmovna mohla na návrh předsedy nebo jiného poslance bez rozpravy prostým hlasováním omezit „dobu řečí při rozpravě povšechné ne pod půl hodiny a při rozpravě podrobné ne pod 10 minut"; $v$ tom prŕpadě platila pro zpravodaje dvojnásobná doba řeči ( $\$ 45$ odst. 6). Praxe byla obvykle taková, že se jednotlivá vystoupení v prvním čtení zkracovala na půl hodiny, ve druhém čtení (které bylo obdobou současného třetího čtení) na 20 minut. Zpravodaj k zákonu měl podle jednacího řádu dvojnásobnou dobu, než byla stanovena pro ostatní řečníky (§ 45 odst. 6). Z hlediska současné praxe, kdy jsou projevy vybraných řečníků (člen vlády, předseda klubu atd., řečníci s tzv. přednostním právem) časově neomezitelné, je třeba podotknout, že omezení řečníka na stanovenou dobu platilo i na členy vlády a ostatní vystupující. 33

Pořadí vyvolávaných poslanců pro př́spěvky $\mathrm{v}$ rozpravě bylo $\mathrm{v}$ zásadě podle pořadí přihlášení, modifikováno ale bylo tím, že mělo být přizpůsobeno pravidlu, že se stř́dají řečníci pro věc a proti věci. Poslanci, kteří chtěli vystoupit, se mohli hlásit před schůzí nebo rozpravou písemně, při rozpravě ústně. $V$ přihlášce bylo třeba uvést, zda řečník vystoupí se stanoviskem pro návrh zákona, nebo proti návrhu. Bylo stanoveno: „předseda uděluje slovo řečníkům zpravidla $v$ pořadí jejich přihlášek, avšak jest povinen přihlížeti $\mathrm{k}$ tomu, aby nejprve mluvil řečník proti návrhu (a to především některý z přihlášených členů výborové minority, která podala zvláštní zprávu) a dále aby se, pokud lze, stř́ídali řečníci pro návrh a proti němu. Promluvil-li již člen některého klubu, udělí předseda jinému téhož klubu slovo teprve tehdy, až promluvili přihlášení řečníci všech klubů, jejichž člen dosud k věci nemluvil.“"34 Tato právní úprava, ve spojení s možností rozpravu ukončit, což bude vysvětleno dále, významným způsobem přibližovala sněmovní rozpravu (v senátu byla shodná regulace) základům parlamentní rozpravy v angloamerickém systému. ${ }^{35}$ Praxe se od jednacích norem poněkud odchylovala, předsedající dával slovo spíše podle pořadí přihlášení, než podle systému pro a proti. ${ }^{36}$

33 Podle zprávy výboru ústavně právního poslanecké sněmovny č. 2272/1933, podle PEŠKA, Z. cit. dílo str. 1232.

34 I úprava o projevech poslanců byla inspirována předchozími jednacími řády. V r. 1863 v Českém sněmu byla úprava obsažena v části jednacího rrádu nazvané řádu mluvení. Každý kdo se chtěl vyjádřit v rozpravě, musel tak osobně a ústně ohlásit ve sněmovní kanceláři a prohlásit, zda bude mluvit pro nebo proti návrhu. Poté, co promluvili zapsaní, je možno dát slovo těm, kteří se hlásí. „Členům sněmu nedovoluje se psaná přednesení čítati.“ (\$ 56). Řečník se nesmí k téže věci vyjádřit více než dvakrát (kromě zpravodaje, maršálka a dalších osob.) Slovo může být odebráno řečníku, pokud byl dvakrát upozorněn na dodržení věci nebo pořádku. In: Jednací ŕád pro český sněm zemský (1867) Praha: tiskem Hynka Fukse, str. 13. Pozděǰš́ verze jednacího řádu Českého sněmu měly úpravu shodnou.

35 Bylo to umožněno rovněž tím, že předseda sněmoven podle jednacího řádu ve věci nehlasoval, což jej přibližovalo k neutrálnímu činiteli, který mohl rozpravu organizovat jako efektivní a věcnou. Řečníci klubu si mohli místa vzájemně vyměňovat. Podobnou úpravu měly už Český sněm v 19. stol.

36 Přes takto racionální předpis nebyla sněmovna spokojena s př́iliš obsáhlými rozpravami. V r. 1933 se proto přistoupilo k opatření, inspirovanému rakouskými jednacími řády - bylo zakázáno běžné projevy číst. Do 
Poznámky osobní a věcné a projevy k jednacímu řádu, což byla obdoba současných faktických poznámek, nesměly za první republiky přesáhnout 5 minut.

Jednací řád obsahoval - stejně jako tehdejší jednací rády některých komor jiných států - možnost ukončit rozpravu ${ }^{37}$. O ukončení rozpravy se hlasovalo, na návrh kteréhokoli poslance, bez rozpravy. Ukončení rozpravy mohlo být odhlasováno až tehdy, když už promluvili v rozpravě k jednacímu bodu alespoň 4 řečníci. Pokud sněmovna rozhodla o ukončení rozpravy, měli právo na projev ,jen hlavní řečník pro návrh a hlavní řečník proti návrhu, ustanovení dohodou zapsaných ještě řečníků obou stran“. Pokud se přihlášení řečníci na hlavních řečnících nedohodli do 5 minut od hlasování o ukončení, museli podle jednacího řádu o řečnících rozhodnout losem úředníci sněmovny, vylosovaní mohli své místo přenechat jinému poslanci. Poté dal předsedající slovo k závěrečným řečem zpravodaji a navrhovateli.

Právní úprava zakazovala výslovně i obstrukce, a to podle vzoru předchozích jednacích řádů. Bylo stanoveno: „Projevy a návrhy, směřující zřejmě k tomu, aby sněmovní jednání mařily nebo svévolně zdržovaly, může předseda se svolením sněmovny vyloučiti z jednání. Sněmovny udílí toho svolení bez rozpravy prostým hlasováním.“38

\section{ZÁVĚR}

Pokud srovnáme současné tendence směřující $\mathrm{k}$ omezení práv jednotlivého poslance podávat návrhy zákonů a pozměňovací návrhy popřs. směřující k omezení projevů poslanců s prvorepublikovou úpravou, je možno velmi jednoduše označit současné snahy za přiblížení se prvorepublikové praxi. Tyto snahy jsou zřetelným odklonem od poslaneckého individualismu, charakterizovaného přebujelými právy jednotlivého poslance, čímž se vyznačuje jednací řád Poslanecké sněmovny z r. 1995, vzniknuvší jako radikální negace socialistické jednomyslnosti.

Prvorepubliková poslanecká legislativní omezení popsaná výše se vyznačují spojením s vyšší poslaneckou stranickou kázní. Tato kázeň byla nezbytná pro multipartijní systém první republiky, zmítaný multinacionálními zájmy roztř́štěného prvorepublikového Národního shromáždění. Zdá se, že zvýšení poslanecké stranické kázně je nezbytné i v současné době. Nástroje a instituty, které jsou v tomto směru momentálně pripravovány, jsou pririrozeně hledány ve způsobech, které už byly v historii vyzkoušeny.

ustanovení § 44 odst. 1 (obou jednacích řádů) bylo vloženo, že „není dovoleno řeči čísti, vyjma projevy předsedy, místopředsedů nebo zpravodajů výborových, členů neb zástupců vlády, stručná prohlášení přednášená jménem klubů a citace s označením pramene. Všichni řečníci však smějí užívati poznámek psaných jen $\mathrm{k}$ podpoře paměti.

37 Návrh na ukončení rozpravu k bodu se nazývá v mezinárodním pojmosloví pravidel parlamentního jednání jako cloture, closure motion nebo guillotine, návrh byl už koncem 19. století používán např. ve Francii, ve Velké Británii a ve Sněmovně reprezentantů USA.

Podle: http://www.ourcommons.ca/marleaumontpetit/DocumentViewer.aspx?Lang=E\&Sec=Ch14\&Seq=3 dne 15. 2. 2018.

38 Toto znění je znění novely z r. 1933, před tím bylo stanoveno: „Je-li předsedovi patrno, že se zneužívá jednacího řádu k tomu, aby bylo jednání mařeno nebo svévolně zdržováno, může veškeré k takovému to počínání směřující projevy a návrhy vyloučiti z jednání se svolením sněmovny, které se udílí bez rozpravy prostým hlasováním.“ 
Není tedy možno říci, že parlamentní jednací řády směřují lineárně $\mathrm{k}$ demokratizaci a širši svobodě výkonu mandátu poslance, jak o tom možná svědčily popřevratové jednací rády v 90 . letech 20 . století. ${ }^{39}$

JUDr. Jindřiška Syllová, CSc.

Parlamentní institut Parlamentu České republiky

syllova@psp.cz

39 Srov. WINTR, J. Jednací řády našich parlamentů od roku 1861. Senát, č. 3, 2002, str. 1-4. 